\title{
The use of meteorological data to assess the cooling service of forests
}

\author{
Xuehui Sun ${ }^{a}$, Xueming Li $^{a}$, Zhangnan Guan ${ }^{a}$, Jian Liu ${ }^{b}$, Shuping Zhang ${ }^{a, *}$ \\ ${ }^{a}$ School of Life Sciences, Shandong University, Jinan, 250100, China \\ ${ }^{b}$ Institute of Environmental Research, Shandong University, Jinan, 250100, China
}

*Corresponding author (Shuping Zhang):

Tel: $86-531-88363573$

Fax: 86-531-88363573

E-mail:spzhang@sdu.edu.cn, shuping.zhang1972@gmail.com 


\begin{abstract}
The climate regulation effects of forests have been extensively studied. Many evaluation methods exist to assess the climate regulation service on regional and global scales. However, the processes driving local scale effects are poorly understood. We established a new method, which combined the cooling effects of forest and cooling costs to assess the value of climate regulation of a local scale forest. The inhabitable value of cooling service of forests for the farming area and built-up area and the payable value only for the built-up area were considered separately. The climate regulation effects of a forest in Fanggan, a mountainous village of East China, were studied. In 2014, the economic value of the cooling effects of the forest was 3727 USD per ha per year. In the inhabitable area, only about $10 \%$ of this amount was practically payable in the built-up area for humans. This method provides a new way of incorporating cooling effects into climate regulation services.
\end{abstract}

Keywords: China; cooling cost; cooling effects; ecosystem services; forest; village; welfare 


\section{Introduction}

Ecosystem services are the direct and indirect contributions of ecosystems to human well-being (TEEB Foundations, 2010; Braat and Groot, 2012). Ecosystem services contain a variety of services, such as supporting services, provisioning services, regulating services and cultural services (Daily, 1997; MEA, 2005; Braat and Groot, 2012; Haines-Young and Potschin, 2013). Accurate assessments of ecosystem services are crucial for policy makers but there are many controversial issues, associated with assessments such as technological advances for data collection, direct measurement of variables, better understanding of human behavioral responses to policy changes (Ouyang et al., 2016).

Climate regulation includes global climate regulation (such as regulation by greenhouse gas or carbon sequestration) and micro and regional climate regulation, for example, local climate can be modified by trees or forest ecosystems, which may involve cooling or humidity changes (TEEB Foundations, 2010; CICES, 2013). Many studies have assessed the values of climate regulation services on a relatively large scale (Seidl and Moraes, 2000; de Groot et al., 2012; Figueroa and Pasten, 2015). In these studies, the cooling service resulting from evapotranspiration, surface albedo, photosynthetic activity and shade can produce lower temperatures (Farrugia et al., 2013).

To assess the economic value of climate regulation service provided by forest ecosystems, a series of indicators and methods, at different scales and targets, have 
been established (Costanza et al., 1997; Xie et al., 2003; Snyder and Twine, 2012; Ouyang et al., 2013). Among these methods, the Market Value (or Price) Method estimates economic values for ecosystem products or services that are bought and sold in commercial markets (Ecosystem valuation website, http://www.ecosystemvaluation.org/market_price.htm). The Willingness-to-Pay Method gives the values of ecosystem products or services based on willingness to purchase. Both methods are widely used ( Costanza et al., 1997; Xie et al., 2003; Xie et al., 2008; Ouyang et al., 2013), but the cooling service of forests is rarely considered and evaluated separately from the climate regulation services. However, the cooling service (cooling part of climate regulation) of a forest is very important for humans during hot summer weather at local scale. Therefore, it is necessary to separate the cooling service of a forest from the climate regulation services.

One method (Ouyang et al., 2013) objectively assessed the climate regulation service of a forest combining the heat absorbing process by plant transpiration and the total cost of electricity used by air conditioning to achieve similar cooling effects. However, this method did not address the actual cooling effects of a forest due to lack of temperature data and did not consider other cooling processes of the forest, such as evapotranspiration, surface albedo, photosynthetic activity and shade. Thus, assessment of the actual cooling effects of the forest is crucial in understanding the forest role in mitigating local heat waves.

The benefits derived from ecosystem services consist of direct (such as food, wood, 
fuel, fresh water) or indirect (such as water and air purification) perceptible components. However, when using economic methods to evaluate the value of ecosystem services, welfare mostly refers to what people perceive and are likely to pay for (Costanza, 2008). Previous research mainly emphasized the directly perceived benefits for humans and ignored the indirect or less perceptible benefits. For example, humans are willing to pay for cooling service inside buildings, but they hardly understand or are unwilling to pay for cooling of the farmland and outdoor areas where they work. Therefore, the cooling service of a forest for a farming area is typically ignored and omitted in methods based on willingness-to-pay.

On a local scale, the climate regulation of an urban forest and other vegetation has been demonstrated (Bastian et al., 2012; Dobbs et al., 2014). Buyadi et al., (2013) showed that urban trees and vegetation play important roles in mitigating the urban heat island effect. Depietri et al., (2013) confirmed the role of the urban forests in lowering the temperature during a heat wave in Cologne, Germany. However, fewer assessments on cooling service provided by forests have been conducted in rural areas, although rural populations and agriculture may be impacted by local climate change (Chmielewski et al., 2004; Tao et al., 2006). Thus, it is important to evaluate the cooling service of forests in rural areas.

To understand the cooling service of a forest on a local scale, we studied the cooling service of a forest in Fanggan, a mountainous village in East China. Fanggan has significantly greater forest coverage $(86.90 \%)$ than surrounding areas. We defined 
the cooling service value of forests for humans in two ways: the inhabitable value (USD per ha per year of the area where people farm and live, including croplands, orchards etc. and built-up area), and the payable value (USD per ha per year of the built-up area, including houses, hotels, and businesses). Using the official meteorological data of Fanggan village and four sites in the surrounding area, we addressed the following questions: (1) What are the cooling effects of the forest, during the hot summer, at Fanggan? (2) What are the inhabitable values and payable values of the forest cooling service? (3) What is a good assessment method that combines the actual cooling effects of the forests and estimated cooling cost?

\section{Methods}

\subsection{Research area and meteorological data}

Fanggan was the research area. It is a small mountainous village with forest coverage of $86.90 \%$ and 579 residents within a 12 ha area. Fanggan is located in the middle of Shandong Province in East China (Figure 1). It has a typical warm temperate continental monsoon climate with four distinct seasons, including a hot, rainy summer. The mean annual temperature of this area is about $12{ }^{\circ} \mathrm{C}$, the mean annual precipitation is about $750 \mathrm{~mm}$, and the frost-free period is approximately $200 \mathrm{~d}$. The dominant landscape types are mountains and hills lower than $1000 \mathrm{~m}$. The village lies at the junction of three cities: Laiwu, Jinan, and Taian.

The forest in Fanggan is mixed, with the dominant tree species being Robinia 
pseudoacacia, Pinus tabuliformis, Pinus koraiensis and Quercus acutissima. The tree composition and species in the surrounding areas are similar. One difference among the study sites is that trees in Fanggan village are protected from harvest and the forested area there is greatest.

The Shiyunshan automatic meteorological station, located on a hilltop close to Fanggan, was used to monitor and record surface climate factors including temperature, precipitation, air humidity and wind. Four other automatic meteorological stations are located at four sites outside of Fanggan, where the forest coverages are lower. These four sites are dominated by farmland, building land, or dwarf shrubs, all lower than $1000 \mathrm{~m}$. These sites were used as controls to evaluate of the cooling service of the forests in Fanggan during the summer months (June to September) (Figure 1).

The daily maximum, minimum and mean temperatures for each site from June to September from 2010 to 2012 were sorted from 24-hour records of each meteorological station. Monthly rainfall of each station from June to September was also collected. The raw meteorological data from the Shiyunshan station, Xueye Lake station, and Dawangzhuang station were provided by the Meteorological Bureau of Laiwu city. Data from Duozhuang and Xiagang stations were provided by Jinan and Taian Meteorological Bureaus, respectively. 


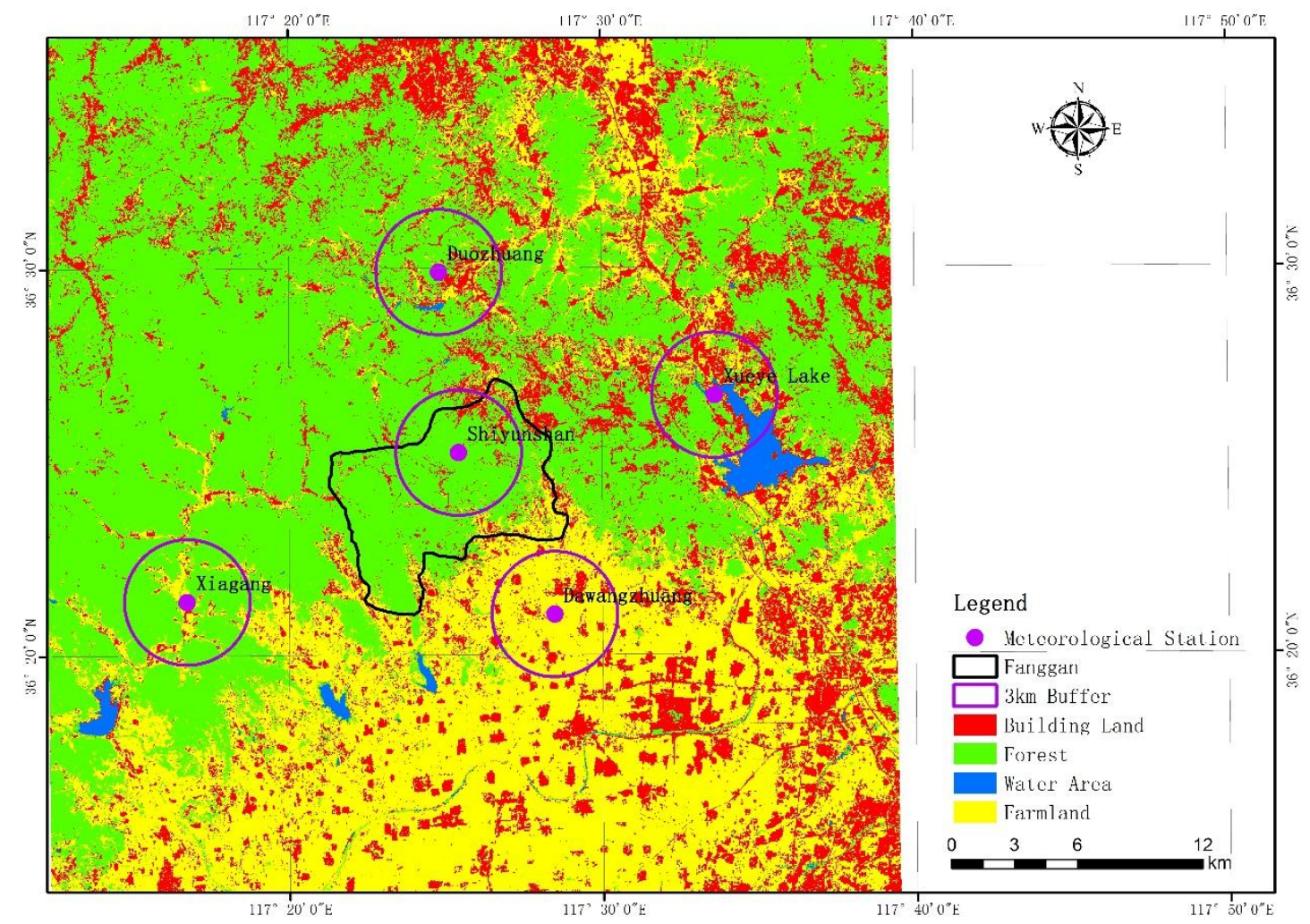

Figure 1. Locations of the five meteorological stations. The $3 \mathrm{~km}$ buffer areas of Shiyunshan station and the other stations, Duozhuang, Xueye Lake, Dawangzhuang, and Xiagang, are shown by purple circles. The area marked by black lines is the administrative boundary of Fanggan village.

\subsection{Effects of elevation and forest coverage}

There might be elevation effects combined with the temperature differences between Fanggan and the other four sites. The <Guidance on the Global Observation System> and <Specification of the ground meteorological observation> (China Meteorological Administration, 2003; WMO, 1993) require that the ground observation site of a weather station should be located in a place that reflects the larger range of meteorological elements of the local area and avoids the influences of local terrain $(\mathrm{He}, 2011)$. The temperature data of the five meteorological stations represent the conditions in villages in which they are located. To rule out the effects of 
elevation, the elevations of the five villages were determined (Table 1). The mean elevation difference between Fanggan and the lower elevations of the four villages is $100 \mathrm{~m}$. So, the temperature difference caused by elevation was estimated to be $0.6{ }^{\circ} \mathrm{C}$ (Xu, 1993; You and Li, 2005).

The forest coverage around each meteorological station was calculated combining interpretation of a remote sensing image, field investigation, and confirmation by local governments. The correlations among mean temperature, mean max temperature of summer months, and forest coverage were analyzed using Spearman Correlation analysis with a bootstrap sampling and two-tailed significance test.

Table 1 The mean altitude and forest coverage of the five buffer areas where the weather stations are located in. (Data from interpretation of a remote sensing image, United States Geological Survey, resolution is $30 \mathrm{~m}$ )

\begin{tabular}{|c|c|c|c|c|}
\hline City & Village & Weather station & $\begin{array}{l}\text { Mean elevation } \\
\text { (meters) }\end{array}$ & $\begin{array}{l}\text { Forest coverage } \\
(3 \mathrm{~km} \text { Buffer })\end{array}$ \\
\hline \multirow{3}{*}{ Laiwu } & Fanggan & Shiyunshan & 535 & $86.90 \%$ \\
\hline & Xueye & Xueye & 375 & $42.20 \%$ \\
\hline & Dawangzhuang & Dawangzhuang & 410 & $0.24 \%$ \\
\hline Jinan & Duozhuang & Duozhuang & 430 & $67.60 \%$ \\
\hline Taian & Xiagang & Xiagang & 420 & $78.40 \%$ \\
\hline
\end{tabular}

\subsection{Evaluations based on existing methods}

To evaluate the cooling service of the forests in Fanggan and to compare the advantages and disadvantages of different methods, we used three methods from previous studies and a new method that combined meteorological data and cooling costs. One of these methods was developed by Costanza et al., (1997). The second 
one was modified by Xie et al., (2003, 2008) and based on Costanza (1997). The third method was proposed by Ouyang et al., (2013). We named the three existing methods as the Costanza method, the Xie method, and the Ouyang method. The effects of the exchange rate and inflation rate (Trading Economics Website, http://zh.tradingeconomics.com/china/inflation-cpi) were adjusted by converting all estimations into USD in 2014.

Based on willingness-to-pay and the supply-demand relationship of ecosystem services, Costanza et al., (1997) determined the climate regulation service of a temperate forest to be 88 USD per ha per year. The total climate regulation service value of the Fanggan village was calculated by multiplying this value by the area (ha) of forests and an inflation rate between 1997 and 2012. Based on the modified Costanza method and a questionnaire survey of 700 ecologists to obtain the equivalent value per unit area of global ecosystem services, Xie et al., (2008) determined the climate regulation service of a forest as 367 USD per ha per year (2014) per ha per year. Therefore, the total climate regulation service of the forests of Fanggan was calculated by multiplying this value by the area (ha) of Fanggan village forests.

Ouyang et al. (2013) established an objective assessment method for determining the cooling service of plants combining heat absorption by transpiration of plants and local cooling cost. According to this method, the cooling service value $\boldsymbol{E} \boldsymbol{v}$ provided by a forest can be calculated using formula (1). 


$$
E v=F a * H a * \rho * P e
$$

where $\boldsymbol{F a}$ is the area of a forest (ha), $\boldsymbol{H a}$ is the absorbed heat by transpiration per area unit of a forest $(\mathrm{kJ} / \mathrm{ha}), \quad \rho$ is a constant to transfer $\mathrm{kJ}$ to $\mathrm{kW} \cdot \mathrm{h}, \boldsymbol{P} \boldsymbol{e}$ is the price of local electricity $(\mathrm{RMB} / \mathrm{kW} \cdot \mathrm{h})$. The cooling service $\boldsymbol{E} \boldsymbol{v}$ was converted into USD of 2014 (Table 3).

\section{4 A new method combining meteorological data and cooling costs}

We developed a new method by combining meteorological data (temperature difference among meteorological sites) and regional electrical cooling costs. This method reflects the objective supply and demand characteristics of the cooling service on a local scale.

\subsubsection{Assessment of the cooling effects of a forest}

Temperature and rainfall data from each site from June to September were collected at the meteorological stations. The June to September period was chosen because air conditioners are frequently used then by local residents for cooling. One-way ANOVA and multiple comparisons (Tukey's multiple range test) were used to compare the differences of monthly maximum temperatures, mean temperatures, and rainfall among the five sites, using Origin 2015 (Origin Lab, Northampton, MA).

\subsubsection{The inhabitable value for humans}

The inhabitable value for humans was determined by calculating the cooling costs for the inhabited areas, including farming, built-up and recreation areas, such as croplands, orchards, housing, and recreation areas of the village using formula (2). 


$$
\mathrm{Ev}=[\mathrm{W} * \mathrm{H} * \mathrm{Pe}] * \mathrm{Si} / \mathrm{Fa}
$$

where $\boldsymbol{W}=\left(\boldsymbol{W o}+\boldsymbol{W} t^{*} \boldsymbol{T t}\right) / \mathbf{1 5 m ^ { 2 }}$, Wo is rated output power $(\mathrm{kW})$ of an air-conditioner, $\boldsymbol{W} \boldsymbol{t}$ is the increased output power $(\mathrm{kW})$ required to decrease the temperature of a 15 $\mathrm{m}^{2}$ room by $1{ }^{\circ} \mathrm{C}\left(\mathrm{kW} /{ }^{\circ} \mathrm{C}\right), \boldsymbol{T t}$ is the total decreased room temperature $\left({ }^{\circ} \mathrm{C}\right), \boldsymbol{H}$ is the total hours of cooling service that should be provided by a forest to the total environment from June to September (h), $\boldsymbol{P e}$ is the local price of electricity $(\mathrm{RMB} / \mathrm{kW} \cdot \mathrm{h}), \boldsymbol{S i}$ is the inhabited area, including farming, built-up and recreation areas of the village $\left(\mathrm{m}^{2}\right), \boldsymbol{F} \boldsymbol{a}$ is the total area of a forest (ha). All the values of parameters are provided in Table 2.

\subsubsection{The payable value for humans}

As people usually choose to stay indoors where the room temperature is controlled by an air conditioner during hot summer days, the actual payable cost for cooling is for the use of air conditioners inside buildings. It is a small fraction of the inhabitable value of the cooling service of a forest. In this case, the payable value for humans can be calculated using formula (3).

$$
E v=[W * H * P e] * S b / F a
$$

where $\boldsymbol{W}, \boldsymbol{H}, \boldsymbol{P e}$, and $\boldsymbol{F a}$ are the same as in formula (2), $\boldsymbol{S b}$ is the built-up area within the village $\left(\mathrm{m}^{2}\right)$. All the values of parameters are given in Table 2 . 
Table 2 Valuation criteria for the existing and newly developed method for evaluating the cooling service of forests

\begin{tabular}{|c|c|c|c|c|c|}
\hline & Methods & & Formula & Parameters & Values of parameters \\
\hline \multirow[t]{6}{*}{ Existing } & Costanza & & - & $E v$ : the value of cooling service of a forest per ha per year (RMB/ha*a) & $\boldsymbol{E} \boldsymbol{v}=88 \mathrm{US} \$ / \mathrm{ha} \cdot \mathrm{a}$ \\
\hline & Xie & & - & $E v$ & $\boldsymbol{E} \boldsymbol{v}=2389.1 \mathrm{RMB} / \mathrm{ha} \cdot \mathrm{a}$ \\
\hline & Ouyang & (1) & $E v=F a^{*} H a * \rho * P e$ & $F a:$ the area of a forest (ha) & $F \boldsymbol{a}=1050$ ha \\
\hline & & & & $\boldsymbol{H} \boldsymbol{a}$ : the absorbed heat by transpiration per area unit of a forest $(\mathrm{kJ} / \mathrm{ha})$ & $\boldsymbol{H a}=8109 \mathrm{~kJ} / \mathrm{ha}$ \\
\hline & & & & $\rho:$ a constant & $\rho=1 \mathrm{~kW} \cdot \mathrm{h} / 3600 \mathrm{~kJ}$ \\
\hline & & & & $P e$ : the local electricity price $(\mathrm{RMB} / \mathrm{kW} \cdot \mathrm{h})$ & $P e=0.5469 \mathrm{RMB} / \mathrm{kW} \cdot \mathrm{h}$ \\
\hline \multirow{11}{*}{$\begin{array}{l}\text { New } \\
\text { established }\end{array}$} & The inhabitable value & (2) & $E v=\left[W^{*} H * P e\right] * S i / F a$ & Wo: the rated output power $(\mathrm{kW})$ of an air-conditioner inverter of $0.735 \mathrm{~kW}$ (Huang & $\boldsymbol{W o}=0.735 \mathrm{~kW}$ \\
\hline & & & $W=\left(W o+W t^{*} T t\right) / 15 m^{2}$ & and Zhou, 2003) & \\
\hline & & & & $\begin{array}{l}\text { Wt: the increased output power }(\mathrm{kW}) \text { to decrease } 1{ }^{\circ} \mathrm{C} \text { of a room of } 15 \mathrm{~m}^{2}\left(\mathrm{~kW} /{ }^{\circ} \mathrm{C}\right) \\
\text { (Huang and Zhou, 2003) }\end{array}$ & $W t=0.0627 \mathrm{~kW} /{ }^{\circ} \mathrm{C}$ \\
\hline & & & & $T t$ : the total decreased room temperature $\left({ }^{\circ} \mathrm{C}\right)$ & $T t=2^{\circ} \mathrm{C}$ \\
\hline & & & & $\boldsymbol{H}$ : the total hours of the cooling service should be provided by a forest to the total & $\boldsymbol{H}=695.4 \mathrm{~h}$ (Zhong and \\
\hline & & & & environment from June to September (h) & Long, 2003) \\
\hline & & & & $P e:$ the local price of electricity $(\mathrm{RMB} / \mathrm{kW} \cdot \mathrm{h})$ & $\boldsymbol{P} \boldsymbol{e}=0.5469 \mathrm{RMB} / \mathrm{kW} \cdot \mathrm{h}$ \\
\hline & & & & $\begin{array}{l}\text { Si: the inhabited areas including farming, built-up and recreation areas, such as } \\
\text { croplands, orchards, housing, and recreation areas }\left(\mathrm{m}^{2}\right)\end{array}$ & $S i=1050000 \mathrm{~m}^{2}$ \\
\hline & The payable value & (3) & $E v=[W * H * P e] * S b / F a$ & $F a$ : the total area of a forest (ha) & $\boldsymbol{F} \boldsymbol{a}=1050$ ha \\
\hline & & & & $S b$ : the built-up areas including private houses, public offices, and business buildings & $S \boldsymbol{b}=100700 \mathrm{~m}^{2}$ \\
\hline & & & & within the village $\left(\mathrm{m}^{2}\right)$ & \\
\hline
\end{tabular}




\section{Results}

\subsection{Cooling effects of the Fanggan forests}

One-way ANOVA analysis on monthly maximum and mean temperatures, and rainfall showed that both the monthly maximum and mean temperature differences among sites were significant $(p<0.05)$, while there was no significant difference among the monthly rainfall values of the five sites (Figure 2). The monthly summer maximum temperature at Shiyunshan was significantly lower than maximum temperature at the other four stations (Figure 2).

(a)

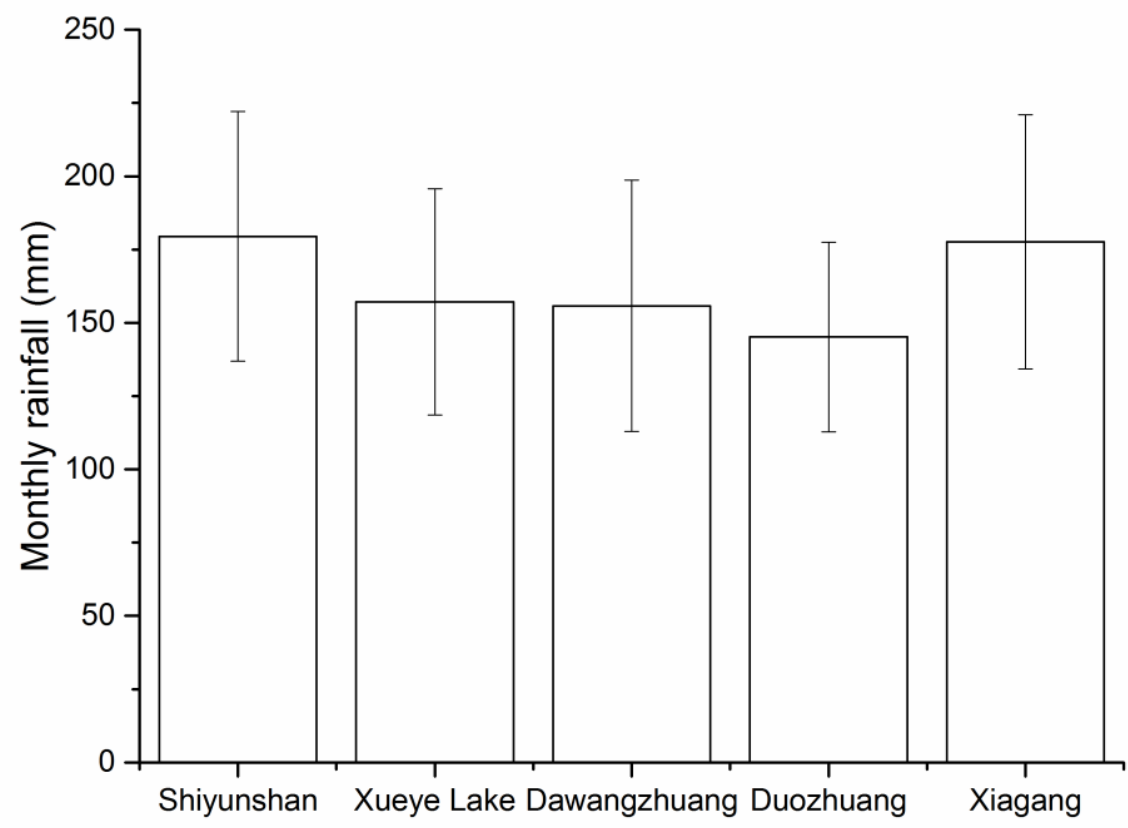


(b)

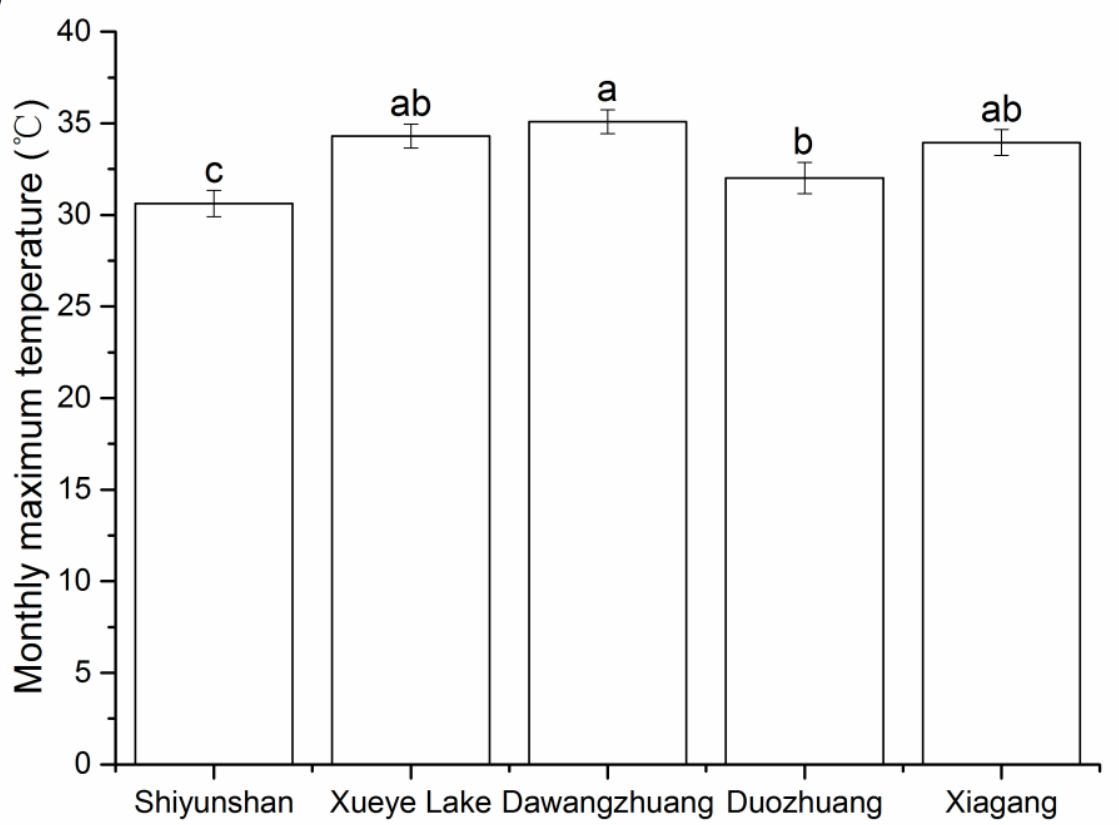

(c)

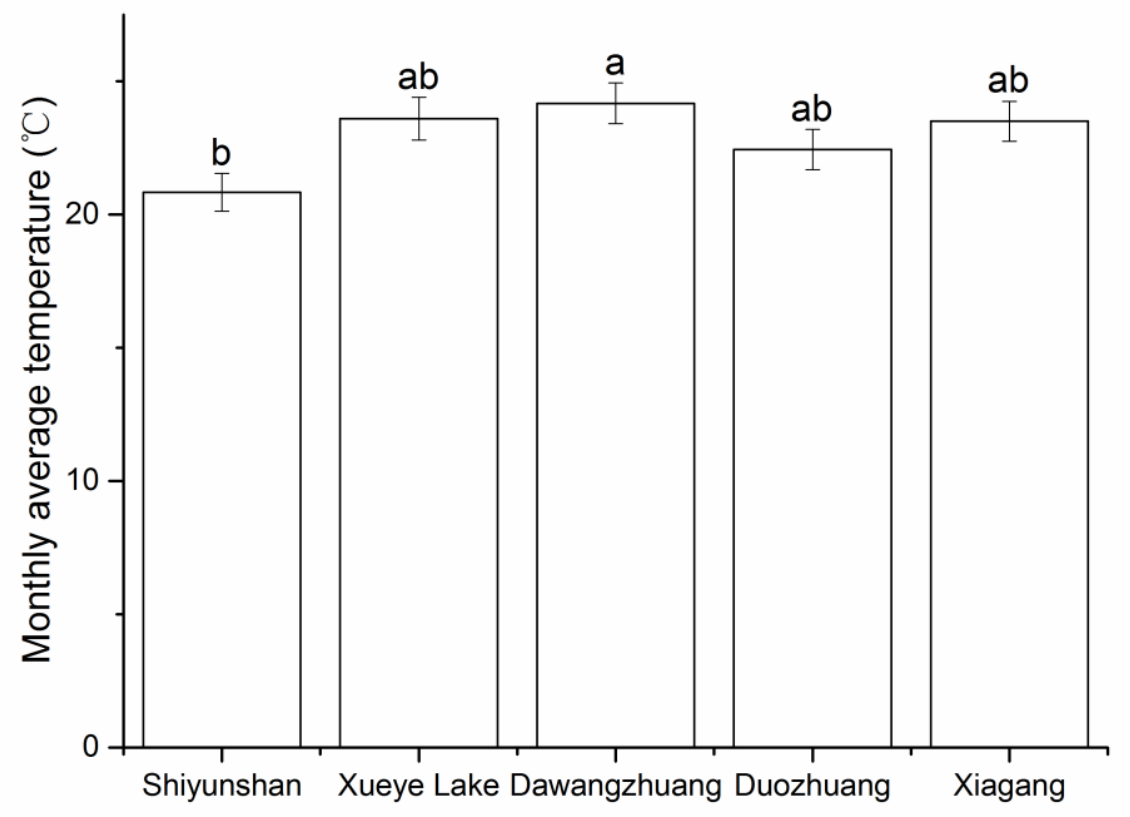

Figure 2 Comparisons of monthly rainfall (a), monthly maximum temperature (b), and monthly mean (average) temperature (c) of the five weather stations from 2010 to 2012. The data are mean \pm SE $(n=12)$. Different letters indicate significant differences $(\mathrm{p} \leq 0.05)$ with Tukey's multiple range test. 
From June to September of 2010-2012, the summer monthly mean and maximum temperature at the Shiyunshan meteorological station were the lowest among the five stations. Spearman Correlation showed that both mean temperature and mean max temperature of summer months at the five stations were significantly negatively correlated with forest coverage $(\mathrm{r}=-0.90, \mathrm{p}=0.037<0.05 ; \mathrm{r}=-0.90, \mathrm{p}=0.037<0.05)$.

The monthly mean temperature of Shiyunshan during summer was $2.6{ }^{\circ} \mathrm{C}$ lower than at the other four stations. Ruling out the temperature difference of $0.6{ }^{\circ} \mathrm{C}$ caused by elevation, we used a mean temperature difference of $2{ }^{\circ} \mathrm{C}$ between Fanggan and the other four sites to calculate the cooling service value of the forests.

\subsection{Cooling service value calculated using existed methods}

According to the Costanza method, the value of the climate regulation service of a temperate forest ecosystem is 88 USD per ha per year. According to the monetary exchange rate of that year, 1 USD was roughly equal to RMB 8.7. So the value of the climate regulation service of a temperate forest was about 224 USD (2014) per ha per year. According to the Xie method, the value of the climate regulation service of the Chinese forests ecosystem was estimated to be 367 USD (2014) per ha per year. According to the Ouyang method, the value of the cooling service of the forests at Fanggan village was calculated to be 221 USD (2014) per ha per year (Table 3).

\subsection{Cooling service combining meteorological data and cooling costs}

Using formula (2), we calculated the inhabitable value of the cooling service of the forests at Fanggan. As the inhabited area within and around the village is 105 ha, and 
the inhabitable value for humans is 3727 USD (2014) per ha per year. We used formula (3), to calculate the payable value of the cooling service of the forests by humans for cooling buildings. It was 357 USD (2014) per ha per year.

\subsection{Comparisons of the four methods}

To compare the values calculated by the different methods, we converted all values into RMB and USD in 2014, respectively (Table 3), by incorporating the inflation and the exchange rates into the equation. There was a large difference among the values based on different methods. Among the values based on the existing methods, the value of the Xie method was the largest, while the value of Ouyang method was the smallest (Table 3). Among the two dimensions of the new established method, the inhabitable value was much higher, while the payable value was close to the value of the Xie method (2008) and about $10 \%$ of the inhabitable value (Table 3).

Table 3 Values of the cooling service of the forests per ha per year presented in RMB and USD of 2014. The inflation rate and exchange rates were taken from Trading Economics (http://zh.tradingeconomics.com/china/inflation-cpi).

\begin{tabular}{lrr}
\hline Method & RMB in 2014 & USD in 2014 \\
\hline Costanza. & 1369 & 224 \\
Xie. & 2245 & 367 \\
Ouyang. & 1352 & 221 \\
Methods combing meteorological data and cooling cost & & \\
Inhabitable value & 22807 & 3727 \\
Payable value & 2187 & 357 \\
\hline
\end{tabular}

\section{Discussion}

The estimated values of cooling service provided by the forests based on different methods and dimensions were different. Each method has its advantages and 
limitations when used to access the cooling service of the forest at a local scale (Table 4) 
Table 4 Advantages and limitations of each method to access the cooling service of the forest at a local scale

\begin{tabular}{|c|c|c|c|c|}
\hline Method & $\begin{array}{l}\text { Applicable } \\
\text { Scales }\end{array}$ & Methodology based on & Advantages & Limitations when applied to local scale \\
\hline Costanza & $\begin{array}{l}\text { Global/ } \\
\text { Regional }\end{array}$ & Willingness-to-pay & $\begin{array}{l}\text { Provide an overall estimate of } \\
\text { temperature and precipitation } \\
\text { regulation services of unit area forest } \\
\text { at global scale. }\end{array}$ & $\begin{array}{l}\text { Cooling service of forest at local scale } \\
\text { may be more important and valuable in } \\
\text { some specific regions and hot summers, } \\
\text { but it might be underestimated in this } \\
\text { method. }\end{array}$ \\
\hline Ouyang & $\begin{array}{l}\text { Provincial/ } \\
\text { Regional }\end{array}$ & $\begin{array}{l}\text { Combing scientific measurement } \\
\text { of heat absorption by plant } \\
\text { evapotranspiration and cooling } \\
\text { cost }\end{array}$ & $\begin{array}{l}\text { Based on scientific measurement of } \\
\text { heat absorption by plants and } \\
\text { calculation of cooling cost. }\end{array}$ & $\begin{array}{l}\text { The cooling service by other biological } \\
\text { processes was not taken into account. }\end{array}$ \\
\hline
\end{tabular}


This could be attributed to the differences in the definition of the cooling service of the forests. Both the Costanza and Xie methods include temperature and precipitation regulation into the climate services (Costanza et al., 1997; Xie et al., 2008). And so, the cooling service of the forests should, to some extent, be lower than the determined values. The Ouyang method defined the cooling service of vegetation as the heat absorption by evapotranspiration (Jim and Chen, 2009; Ouyang et al., 2013). However, this method does not consider the other biologically mediated cooling processes such as photosynthesis and reflection (Renaud and Rebetez, 2009). Thus, the value based on the Ouyang method might be an underestimate. Our new method considered the cooling service of the forests from June to September. As such, the cooling service of the forest would be underestimated.

The differences among methods could result in different assessment values. Both the Constanza and Xie methods are directly or indirectly based on willingness-to-pay, which can be influenced by the socioeconomic context as well as perceptions of interviewees on ESV (Ecosystem Services Value). Thus, the two methods obtained different values based on the willingness-to-pay of different respondents. Both the Ouyang method and the new method are based on the observed data and formulas that compile ecological processes. Objective methods can also obtain different results as they use different data and formulas combined with the effects of definitions. Overall the Xie method and the inhabitable value based on the new method consider most human needs of the cooling service. Hence, we suggest that both methods have 
practical applications for ecosystem services management.

In addition, spatial scale has been a main concern of ecosystem services assessment (de Groot et al., 2012; Ninan and Inoue, 2013). The cooling effects of forests on a regional or global scale are widely studied but local-scale studies are less common (Lin et al., 2006; Liang and Lin, 2007; Liu et al., 2013). Thus, our new method has focused on the cooling service of local-scale forests. The Costanza method, Xie method, and Ouyang method were developed for assessment at the global, national, and provincial scales, respectively, so these methods may be less relevant to local and smaller scales. Therefore, we focused on the real cooling effects of a forest on a local scale using the new method. To provide a practical assessment of the cooling service of a forest at a local scale using the new method, a step-by-step work flow chart is given (Fig. 3).

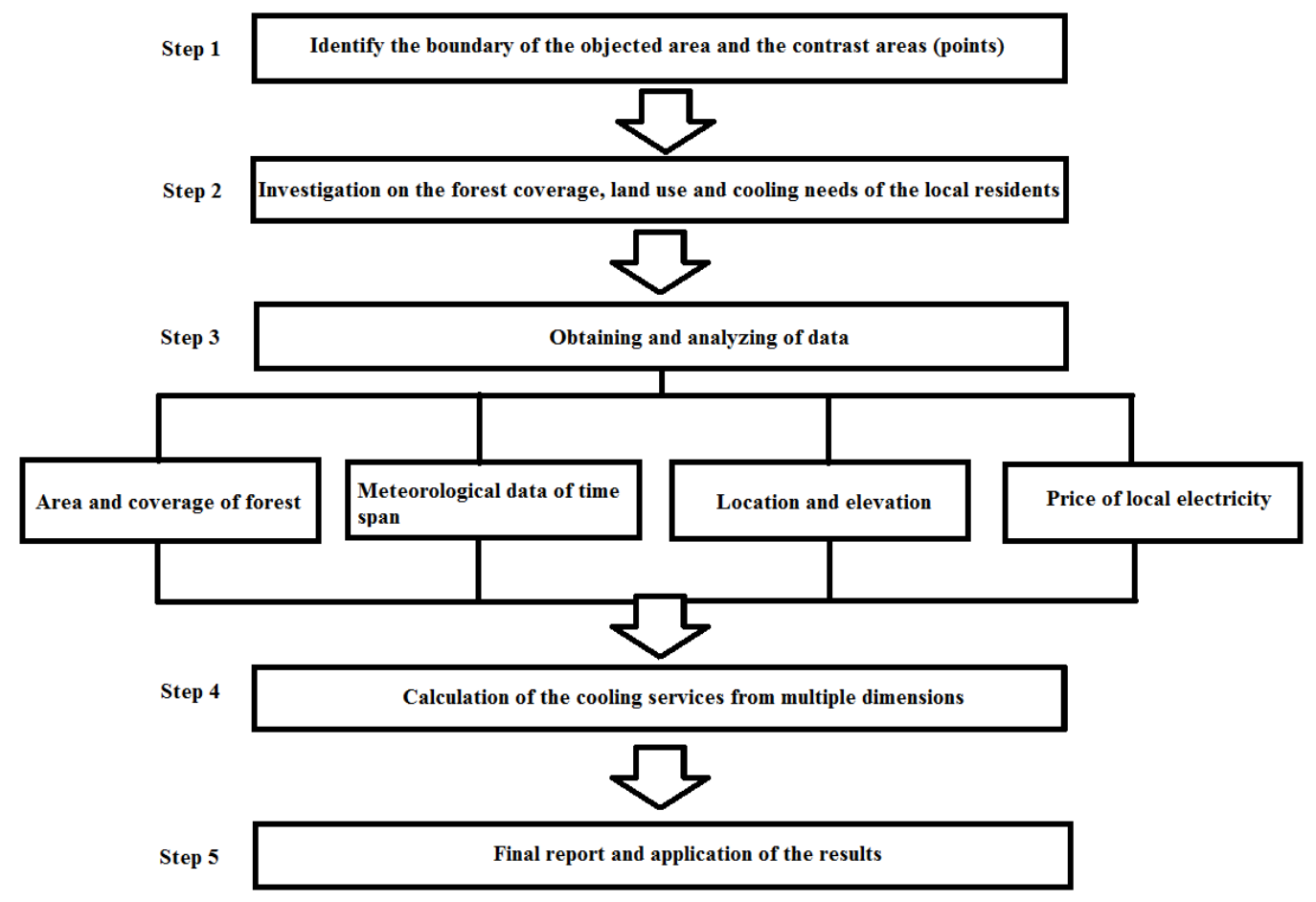


Figure 3 Work flow chart for assessing the cooling service of a local-scale forest using the new method.

Our results support the hypothesis that there is a gap between the real cooling service of a forest and the perception and willingness-to-pay by humans at a local scale. Franchini and Mannucci (2015) demonstrated that climate change has critical impacts on human health and the livelihood of communities. Slight changes in temperature can result in significant influences on the development and behaviors of animals and pathogens (Walther et al., 2002; Thomson et al., 2010; Wernberg et al., 2011; Vo et al., 2012). Therefore, changes in temperature can produce impacts on biodiversity and ecosystem services (MA, 2005; Masur and Posner, 2011). Although the payable value is only a small part of the inhabitable value, the contrasting levels of the cooling service values in different aspects provide new insight into the climate regulation service of local-scale forests.

\section{Conclusion}

A new method was used to assess the cooling service of a local-scale forest. The inhabitable value and the payable value for humans were found to be different. The potential value, which supports the sustainability of the whole environment, may be greater than the inhabitable and the payable values and should be given great consideration (Bonan, 2008; Jim and Chen, 2009). The new method is a useful tool for assessing the cooling service of local-scale forests. Future research should 
investigate the cooling service of forests under different plant community contexts such as different tree species composition and biodiversity levels.

\section{Acknowledgements}

This work was supported by the National Key Technology R\&D Program (No. 2013BAJ10B0403), Shandong Provincial Science and Technology Development Program (No. 2010GSF10618) and "The Fundamental Research Funds of Shandong University" (No. 2015JC023). We thank Prof. D. Huisingh, University of Tennessee, for his critical review of the manuscript and Dr. E. C. Mignot, Shandong University, for linguistic advice. We also thank Accdon for its linguistic assistance during the preparation of this manuscript. Thanks USGS for its remote sensing image.

\section{References:}

Assessment, M.E., 2005. Ecosystems and human well-being. Island Press Washington, DC.

Assessment, M.E., 2005. Ecosystems and Human Well-being: Current State and Trends 1.

Bastian, O., Haase, D., Grunewald, K., 2012. Ecosystem properties, potentials and services-the EPPS conceptual framework and an urban application example. Ecological Indicators 21, 7-16.

Bonan, G.B., 2008. Forests and climate change: forcings, feedbacks, and the climate 
benefits of forests. Science 320, 1444-1449.

Buyadi, S.N.A., Mohd, W.M.N.W., Misni, A., 2013. Green Spaces Growth Impact on the Urban Microclimate. Procedia - Social and Behavioral Sciences, AicE-Bs 2013 London (Asia Pacific International Conference on Environment-Behaviour Studies), 4-6 September 2013 105, 547-557.

Braat, L.C., Groot, R.D., 2012. The ecosystem services agenda:bridging the worlds of natural science and economics, conservation and development, and public and private policy. Ecosystem Services 1, 4-15.

China Meteorological Administration. Specification of the ground meteorological observation. [M]. Edition 1. Beijing: Meteorological Press, 2003.

Chmielewski, F.-M., Müller, A., Bruns, E., 2004. Climate changes and trends in phenology of fruit trees and field crops in Germany, 1961-2000. Agricultural and Forest Meteorology 121, 69-78.

Costanza, R., 2008. Ecosystem services: multiple classification systems are needed. Biological conservation 141, 350-352.

Costanza, R., d’ Arge, R., Groot, R. de, Farber, S., Grasso, M., Hannon, B., Limburg, K., Naeem, S., O’Neill, R.V., Paruelo, J., 1997. The value of the world's ecosystem services and natural capital. Nature 387, 253-260.

CICES Version 4.3 , http://biodiversity.europa.eu/maes/common-international-classification-of-eco system-services-cices-classification-version-4.3 
Daily, G.C., 1997. Nature's Services: Societal Dependence On Natural Ecosystems. Natures Services Societal Dependence on Natural Ecosystems 1, 220-221.

De Groot, R., Brander, L., van der Ploeg, S., Costanza, R., Bernard, F., Braat, L., Christie, M., Crossman, N., Ghermandi, A., Hein, L., Hussain, S., Kumar, P., McVittie, A., Portela, R., Rodriguez, L.C., ten Brink, P., van Beukering, P., 2012. Global estimates of the value of ecosystems and their services in monetary units. Ecosystem Services 1, 50-61.

De Groot, R.S., Wilson, M.A., Boumans, R.M.J., 2002. A typology for the classification, description and valuation of ecosystem functions, goods and services. Ecological Economics 41, 393-408.

Depietri, Y., Welle, T., Renaud, F.G., 2013. Social vulnerability assessment of the Cologne urban area (Germany) to heat waves: links to ecosystem services. International Journal of Disaster Risk Reduction 6, 98-117.

Dobbs, C., Kendal, D., Nitschke, C.R., 2014. Multiple ecosystem services and disservices of the urban forest establishing their connections with landscape structure and sociodemographics. Ecological Indicators 43, 44-55.

Farrugia, S., Hudson, M.D., McCulloch, L., 2013. An evaluation of flood control and urban cooling ecosystem services delivered by urban green infrastructure. Int. J. Biodivers. Sci. Ecosyst. Serv. Manag. 9, 136-145.

Figueroa, E.B., Pasten, R.C., 2015. The economic value of forests in supplying local climate regulation. Australian Journal of Agricultural and Resource 
Economics.

Franchini, M., Mannucci, P.M., 2015. Impact on human health of climate changes. European Journal of Internal Medicine 26, 1-5.

Haines-Young, R., Potschin, M., 2013. Common International Classification of Ecosystem Services (CICES): Consultation on Version 4, August-December 2012. EEA Framework Contract No EEA. Contract No EEA/IEA/09/003.

He, C., 2011. The site selection and construction of weather station. Modern

Agricultural Science and Technology 43-44. (in Chinese)

http://zh.tradingeconomics.com/china/inflation-cpi， n.d. Chinese-Inflation- 2014

[WWW Document]. URL http://zh.tradingeconomics.com/china/inflation-cpi (accessed 4.3.15).

http://www.ecosystemvaluation.org/market_price.htm

Huang, Z., Zhou, H., 2003. The study of the relationship between household air condition temperature setting and electricity consumption. Shanghai refrigeration institute academic essays collection of the year 2003 4. (in Chinese)

Jim, C.Y., Chen, W.Y., 2009. Ecosystem services and valuation of urban forests in China. Cities 26, 187-194.

Liang, J., Lin, Y., 2007. Temporal and Spatial Patterns of Peripheral Environment Influenced by Urban Forest. Chinese Agricultural Science Bulletin 379-385. (in Chinese) 
Lin, Y., Han, X., Wu, X., Hao, X., Wang, J., Liang, F., Liang, J., Wang, Z., 2006. Ecological Field Characteristic of Green Land Based on Urban Green Space Structure. Acta Ecologica Sinica 3339-3346. (in Chinese)

Liu, Q., Liu, Y., Li, C., 2013. Study on the Effect of Urban Forest Plaque on Temperature and Humidity. Chinese Agricultural Science Bulletin 35-39. (in Chinese)

Masur, J.S., Posner, E.A., 2011. Climate regulation and the limits of cost-benefit analysis. California Law Review 99, 1557.

MEA, 2005. Millennium Ecosystem Assessment Synthesis Report. Island Press Washington, DC, USA.

Ninan, K.N., Inoue, M., 2013. Valuing forest ecosystem services: What we know and what we don't. Ecological Economics 93, 137-149.

Ouyang, Z., Zheng, H., Xiao, Y., Polasky, S., Liu, J., Xu, W., Wang, Q., Zhang, L., Xiao, Y., Rao, E., 2016. Improvements in ecosystem services from investments in natural capital. Science 352, 1455-1459.

Ouyang, Z., Zhu, C., Yang, G., Xu, W., Zheng, H., Zhang, Y., Xiao, Y., 2013. Gross ecosystem product: concept, accounting, framework and case study. Acta Ecologica Sinica 6747-6761. (in Chinese)

Renaud, V., Rebetez, M., 2009. Comparison between open-site and below-canopy climatic conditions in Switzerland during the exceptionally hot summer of 2003. Agricultural and Forest Meteorology 149, 873-880. 
Seidl, A.F., Moraes, A.S., 2000. Global valuation of ecosystem services: application to the Pantanal da Nhecolandia, Brazil. Ecol. Econ. 33, 1-6. doi:10.1016/S0921-8009(99)00146-9

Snyder, P.K., Twine, T.E., 2012. Climate regulation services of natural and agricultural ecoregions of the Americas. Nat. Clim. Change 177-181.

Tao, F., Yokozawa, M., Xu, Y., Hayashi, Y., Zhang, Z., 2006. Climate changes and trends in phenology and yields of field crops in China, 1981-2000. Agricultural and Forest Meteorology 138, 82-92.

TEEB Foundations, 2010. In: Kumar, P. (Ed.), TEEB-The Economics of Ecosystems and Biodiversity (TEEB): Ecological and Economic Foundations. Earthscan, London.

Thomson, L.J., Macfadyen, S., Hoffmann, A.A., 2010. Predicting the effects of climate change on natural enemies of agricultural pests. Biological Control, Australia and New Zealand Biocontrol Conference 52, 296-306.

Vo, Q.T., Kuenzer, C., Vo, Q.M., Moder, F., Oppelt, N., 2012. Review of valuation methods for mangrove ecosystem services. Ecological Indicators 23, 431-446.

Walther, G.-R., Post, E., Convey, P., Menzel, A., Parmesan, C., Beebee, T.J.C., Fromentin, J.-M., Hoegh-Guldberg, O., Bairlein, F., 2002. Ecological responses to recent climate change. Nature 416, 389-395.

Wernberg, T., Russell, B.D., Moore, P.J., Ling, S.D., Smale, D.A., Campbell, A., Coleman, M.A., Steinberg, P.D., Kendrick, G.A., Connell, S.D., 2011. Impacts 
of climate change in a global hotspot for temperate marine biodiversity and ocean warming. Journal of Experimental Marine Biology and Ecology, Global change in marine ecosystems 400, 7-16.

WMO, 1993. Instruments and Observing Methods Report No. 55 [WWW Document]. URL https://www.wmo.int/pages/mediacentre/press_releases/documents.

Origin2015, 2015. http://www.originlab.com/

Xie, G., Lu, C., Leng, Y., Zheng, D., Li, S., 2003. The evaluation of Qinghai-Tibet plateau ecological asset. Journal of Natural Resources 189-196. (in Chinese)

Xie, G., Zhen, L., Lu, C., Xiao, Y., Chen, C., 2008. Expert Knowledge Based Valuation Method of Ecosystem Services in China. Journal of Natural Resources 911-919. (in Chinese)

Xu, S., 1993. Base of Atmospheric Physics. Meteorological Press. (in Chinese)

You, S., Li, J., 2005. Study on Error and Its Pervasion of Temperature Estimation. Journal of Natural Resource. 20, 140-144. (in Chinese)

Zhong, T., Long, W., 2003. The investigation of residential air condition and evaluation of electricity consumption in Shanghai. Building Energy \& Environment 22-24. (in Chinese) 